\title{
Nitrogen Rate, Cultivar, and Within-row Spacing Affect Collard Yield and Leaf Nutrient Concentration
}

\author{
James M. Dangler ${ }^{1}$ and C. Wesley Wood ${ }^{2}$ \\ Alabama Agricultural Experiment Station, Auburn University, AL 36849-5408
}

Additional index words, Brassica oleracea (Acephala Group), fertilizer, plant nutrition, plant population, vegetable nutrition

\begin{abstract}
Collards (Brassica oleracea L. Acephala Group) were grown in spring and fall to evaluate the effects of $\mathrm{N}$ fertilizer rate $\left(0,56,112,168\right.$, and $\left.224 \mathrm{~kg}^{\circ} \mathrm{ha}^{-1}\right)$, cultivar (Blue Max and Vates), and within-row spacing $(15,23$, and $30 \mathrm{~cm})$ on yield and leaf mineral nutrient concentrations. Season, cultivar, and $\mathrm{N}$ rate interacted in their effects on yield. In spring, 'Blue Max' yield increased linearly with $\mathrm{N}$ rate to $10.4 \mathrm{t} \cdot \mathrm{ha}^{-1}$, whereas the highest 'Vates' yield (7.0 t'ha' ${ }^{-1}$ ) was obtained with $112 \mathrm{~kg} \mathrm{~N} / \mathrm{ha}$, and yield remained similar with additional $\mathrm{N}$. In fall, 'Blue Max' and 'Vates' yields were highest (14.5 and $9.9 \mathrm{t} \cdot \mathrm{ha}^{-1}$, respectively) with $112 \mathrm{~kg} \mathrm{~N} / \mathrm{ha}$. Leaf $\mathrm{N}$ and $P$ concentrations increased quadratically and linearly, respectively, in response to $\mathrm{N}$ rate. Maximum yields were obtained with the $15-\mathrm{cm}$ within-row spacing. Leaf $\mathbf{N}$ concentration increased linearly with increased plant population. The adequacy of the present sufficiency range for leaf Ca concentrations of field-grown collards is discussed.
\end{abstract}

High plant population densities and $\mathrm{N}$ fertilizer rates are used to increase crucifer yields. High cabbage (Brassica oleracea L. Capitata Group) populations have produced higher yields but lower head weights (Csizinszky and Shuster, 1985; Knavel and Heron, 1981; Stofella and Fleming, 1990; White and Forbes, 1976) and increased variation in whole-plant, root, and head weights (Stofella and Fleming, 1990) compared to low plant populations. A positive response to $\mathrm{N}$ application up to 370 $\mathrm{kg} \cdot \mathrm{ha}^{-1}$ has been reported (Knave] and Heron, 1981). The response of broccoli (B. oleracea L. Botrytis Group) to plant spacing (Cutcliffe, 1975; Massey et al., 1962; Palevitch, 1970) or fertilizer rate (Beverly et al., 1986; Kowalenko and Hall, 1987; Letey et al., 1983) has been documented. Linear increases in marketable broccoli yields and head weights were obtained with up to $224 \mathrm{~kg} \mathrm{~N} / \mathrm{ha}$ and 72,000 plants/ha (Dufault and Waters, 1985).

The response of Chinese vegetables to $\mathrm{N}$ rates and within-row spacing has been reported (Hill, 1990). High yields of Chinese kale (B. oleracea L. Alboglabra Group) occurred at the closest spacing used $(10 \times 30 \mathrm{~cm})$, and yields increased with the highest rate used $-400 \mathrm{~kg} \mathrm{~N} / \mathrm{ha}$. At lower plant densities, maximum yields were produced at $200 \mathrm{~kg} \mathrm{~N} /$ ha. Low head weights were obtained with close within-row spacings. The positive yield response of false pak choi (B. parachinensis L.H. Bailey) to close within-row spacings was

\footnotetext{
Received for publication 19 Aug. 1992, Accepted for publication 16 Feb. 1993. Alabama Agricultural Experiment Station journal series no. 11-923320. The cost of publishing this paper was defrayed in part by the payment of page charges. Under postal regulations, this paper therefore must be hereby marked advertisement solely to indicate this fact. ${ }^{1}$ Dept. of Horticulture.

${ }^{2}$ Dept. of Agronomy and Soils.
}

more pronounced at all $\mathrm{N}$ rates than that of kai lan, but the effect of $\mathrm{N}$ rates was not as great. Tsoi sum (false pak choi) yields increased at $200 \mathrm{~kg} \mathrm{~N} / \mathrm{ha}$, then remained constant. Similar high yields of pak choi (B. rapa L. Chinensis Group) were obtained at the $10-$ or $20-\mathrm{cm}$ within-row spacings with $200 \mathrm{~kg} \mathrm{~N} / \mathrm{ha}$; however, plant weights at $10 \mathrm{~cm}$ were much lower than at the other spacings. Applying additional $\mathrm{N}$ increased the incidence of soft rot and reduced yields.

Unlike most crucifers, turnips (B. rapa L. Rapifera Group) (Kahn, 1990) and collards (Johnson, 1991a) grown for fresh market and processing are usually established by direct seeding in the field. Because of the increased cost of hybrid seed and the convenience of obtaining quality transplants, collard establishment has shifted to using transplants (Olson and Stofella, 1989). The effects of within-row spacing and $\mathrm{N}$ rate on collard production, however, have not been addressed. The objective of this work, therefore, was to examine the seasonal effects of cultivar, fertilizer $\mathrm{N}$ rate, and within-row spacing on collard yields and leaf mineral nutrient concentrations.

Field experiments were conducted in Spring and Fall 1990 on a Norfolk-Orangeburg loamy sand association (fine, loamy, siliceous, thermic Typic Kandiudults) at the E.V. Smith Research Station near Shorter, Ala. Selected characteristics of the study site soils (0 to 15 $\mathrm{cm}$ deep) were $\mathrm{pH}, 6.3$; organic matter, $1.4 \%$; and cation-exchange capacity, $4.7 \mathrm{meq} / 100 \mathrm{~g}$ (Perkins, 1987). Melich I-extractable nutrients (in mg.liter ${ }^{-1}$ ) were $\mathrm{P}, 55 ; \mathrm{K}, 69 ; \mathrm{Ca}, 158$; and $\mathrm{Mg}, 54$ (Hue and Evans, 1986). Treatments were factorial combinations of $\mathrm{N}$ rate $\left(0,56,112,168\right.$, and $224 \mathrm{~kg} \cdot \mathrm{ha}^{-1}$ as $\left.\mathrm{NH}_{4} \mathrm{NO}_{3}\right)$, collard cultivar ('Blue Max' and 'Vates'), and within-row spacing $(15,23$, and $30 \mathrm{~cm})$ within a split-plot design. Nitrogen rates were assigned to main plots; within-row spacing and cultivar combinations were subplots. Treatments were replicated four times in one-row plots $9.1 \mathrm{~m}$ long spaced $1.2 \mathrm{~m}$ apart.

Phosphorus (concentrated superphosphate) and $\mathrm{K}(\mathrm{KCl})$ were broadcast and incorporated at rates of (in $\mathrm{kg} \cdot \mathrm{ha}^{-1}$ ) 29P-56K and 10P-19K in spring and fall, respectively. One-half of the $\mathrm{N}$ was broadcast and incorporated at planting; the remainder was band-applied 30 days after planting. a,a,a-Trifluoro-2,6-dinitro-N,N-dipropyl $-p$-toluidine (trifluralin) (0.473 liters.ha $\left.{ }^{-1}\right)$ and $O$ - ethyl $S, S$ - dipropyl phosphodithionate (ethoprop) (0.486 liters'ha ${ }^{-1}$ ) were broadcast and incorporated for weed and nematode control.

'Blue Max' (Abbott and Cobb, Feasterville, $\mathrm{Pa}$.) and 'Vates' collard transplants ( 150-size TODD planter flats, Speedling, Sun City, Fla.) were planted on 28 Mar. and 12 Sept. 1990,15, 23 , and $30 \mathrm{~cm}$ apart in rows spaced $1.2 \mathrm{~m}$ to provide populations of $55,600,36,200$, and 27,800 plants/ha, respectively. Total rainfall and overhead irrigation during spring and fall were 220 and $190 \mathrm{~mm}$, respectively. The fungicide tetrachloroisophthalonitrile (chlorothalonil) (0.42 liters $\left.\cdot \mathrm{ha}^{-1}\right)$ and the insecticide Bacillus thuringensis var. kurstaki $(0.560$ $\left.\mathrm{kg} \cdot \mathrm{ha}^{-1}\right)$ were applied weekly for disease and insect control, respectively.

Plants were harvested once at the 21-leaf stage on 18 May and 13 Nov. 1990. Before harvest, recently mature whole leaves were collected for nutrient analyses. Tissue was dried in a forced-air drier at $70 \mathrm{C}$ and ground to $<0.6 \mathrm{~mm}$. Tissue $\mathrm{N}$ concentrations were determined by dry combustion with an analyzer (model CHN-600; LECO Corp., St. Joseph, Minn.). Total P, K, Ca, and $\mathrm{Mg}$ concentrations were analyzed by inductively coupled plasma spectroscopy (Hue and Evans, 1986).

Data were subjected to analysis of variance procedures. The main effects of $\mathrm{N}$ rate and within-row spacing and their interactions were partitioned using single-degree-of-freedom contrasts.

Higher collard yields were obtained in fall than in spring (Table 1); however, season, $\mathrm{N}$ rate, and cultivar interacted in their effects on yield (Table 2). In spring, 'Blue Max' yield increased linearly, but 'Vates' yield increased quadratically, with the highest yields at $112 \mathrm{~kg}$ $\mathrm{N} / \mathrm{ha}$. In fall, both cultivar yields responded quadratically, with the highest yields at $112 \mathrm{~kg}$ $\mathrm{N} / \mathrm{ha}$. The superiority of 'Blue Max' was evident at $0 \mathrm{~kg} \mathrm{~N} / \mathrm{ha}$; its yield was $\approx 100 \%$ higher than that of 'Vates'. Higher biomass production by 'Blue Max' than 'Vates' has been reported in field, nutrient solution, and sand culture experiments (Johnson, 1991a; Olson and Stofella, 1989); the former attributed 'Blue Max' productivity to its large root system,

In addition to higher yields, higher leaf nutrient concentrations (except $\mathrm{Ca}$ ) were obtained in fall than in spring (Table 1). Season and cultivar interacted only in their effects on leaf $\mathrm{N}$ concentrations (Table 3). Although higher yields were obtained for 'Blue Max' than 'Vates' in both seasons, similar leaf $\mathrm{N}$ concentrations were obtained for both cultivars in fall; but, in spring, $\mathrm{N}$ concentration was higher for 'Vates' than 'Blue Max'. In both 
Table 1. Effects of season, $\mathrm{N}$ rate, cultivar, and within-row plant spacing on collard yield and leaf nutrient concentrations.

\begin{tabular}{|c|c|c|c|c|c|c|}
\hline & \multirow{2}{*}{$\begin{array}{c}\text { Yield } \\
\left(\mathbf{t} \cdot \mathrm{ha}^{-1}\right)\end{array}$} & \multicolumn{5}{|c|}{ Nutrient concn (\%) } \\
\hline & & $\mathbf{N}$ & $P$ & $\mathrm{~K}$ & $\mathrm{Ca}$ & $\mathrm{Mg}$ \\
\hline \multicolumn{7}{|l|}{ Season (S) } \\
\hline Spring & 6.3 & 4.22 & 0.51 & 3.27 & 1.50 & 0.35 \\
\hline Fall & 10.3 & 5.58 & 0.61 & 4.20 & 1.66 & 0.40 \\
\hline Significance & $* * *$ & $* * *$ & * & $* * *$ & NS & $*$ \\
\hline \multicolumn{7}{|c|}{$\mathrm{N}$ rate $(\mathrm{N})\left(\mathrm{kg} \cdot \mathrm{ha}^{-1}\right)$} \\
\hline 0 & 4.2 & 3.82 & 0.52 & 3.68 & 1.66 & 0.38 \\
\hline 56 & 7.9 & 4.68 & 0.53 & 3.77 & 1.56 & 0.37 \\
\hline 112 & 9.6 & 4.93 & 0.56 & 3.83 & 1.52 & 0.36 \\
\hline 168 & 9.9 & 5.45 & 0.60 & 3.69 & 1.51 & 0.38 \\
\hline 224 & 9.8 & 5.61 & 0.59 & 3.70 & 1.62 & 0.39 \\
\hline Significance & $Q^{* * *}$ & $Q^{* *}$ & $\mathrm{~L}^{* * *}$ & NS & NS & NS \\
\hline \multicolumn{7}{|l|}{ Cultivar (C) } \\
\hline Blue Max & 9.8 & 4.78 & 0.56 & 3.85 & 1.41 & 0.34 \\
\hline Vates & 6.9 & 5.01 & 0.56 & 3.61 & 1.74 & 0.41 \\
\hline Significance & $* * *$ & $* * *$ & NS & $* * *$ & $* * *$ & $* * *$ \\
\hline \multicolumn{7}{|l|}{ Interaction ${ }^{2}$} \\
\hline $\mathrm{Y} \times \mathrm{C}$ & ** & $* * *$ & NS & NS & NS & NS \\
\hline $\mathrm{S} \times \mathrm{N} \times \mathrm{C}$ & ** & NS & NS & NS & NS & NS \\
\hline \multicolumn{7}{|l|}{ Spacing $(\mathrm{cm})$} \\
\hline 15 & 8.9 & 4.77 & 0.55 & 3.75 & 1.6 & 0.39 \\
\hline 23 & 8.0 & 4.90 & 0.56 & 3.74 & 1.6 & 0.38 \\
\hline 30 & 7.9 & 5.02 & 0.57 & 3.71 & 1.5 & 0.36 \\
\hline Significance & $\mathrm{Q}^{*}$ & $\mathbf{L}^{*}$ & NS & NS & NS & NS \\
\hline
\end{tabular}

${ }^{2}$ No other interactions were significant.

Ns, * **, *** Nonsignificant or significant at $P=0.05,0.01$, or 0.001 , respectively; $\mathrm{L}=$ linear, $\mathrm{Q}=$ quadratic.

Table 2. Interaction of season, cultivar, and $\mathrm{N}$ rate on collard yield

\begin{tabular}{|c|c|c|c|c|c|c|}
\hline \multirow[b]{3}{*}{ Cultivar } & \multicolumn{5}{|c|}{ Yield $\left(\mathrm{t} \cdot \mathrm{ha}^{-1}\right)$} & \multirow[b]{3}{*}{ Significance } \\
\hline & \multicolumn{5}{|c|}{$\mathrm{N}$ rate $\left(\mathrm{kg} \cdot \mathrm{ha}^{-1}\right)$} & \\
\hline & 0 & 56 & 112 & 168 & 224 & \\
\hline \multicolumn{7}{|c|}{ Spring } \\
\hline Blue Max & 2.8 & 6.2 & 6.9 & 8.6 & 10.4 & $L^{* * *}$ \\
\hline Vates & 2.2 & 4.6 & 7.0 & 7.1 & 7.0 & $\mathrm{Q}^{* * *}$ \\
\hline \multicolumn{7}{|c|}{ Fall } \\
\hline Blue Max & 8.1 & 12.8 & 14.5 & 14.8 & 12.9 & $Q^{\star * *}$ \\
\hline Vates & 3.9 & 8.2 & 9.9 & 9.0 & 9.0 & $Q^{* * *}$ \\
\hline
\end{tabular}

${ }^{* * *}$ Significant at $P \leq 0.001 ; \mathrm{L}=$ linear, $\mathrm{Q}=$ quadratic.

Table 3. Interaction of season and cultivar on leaf $\mathrm{N}$ concentration.

\begin{tabular}{llr}
\hline & \multicolumn{2}{c}{ Leaf N concn (\%) } \\
\cline { 2 - 3 } & \multicolumn{2}{c}{ Cultivar } \\
\cline { 2 - 3 } Season & \multicolumn{1}{c}{ Blue Max } & Vates \\
\hline Spring & $4.02 \mathrm{~b}^{2}$ & $4.41 \mathrm{a}$ \\
Fall & $5.54 \mathrm{a}$ & $5.62 \mathrm{a}$ \\
\hline
\end{tabular}

${ }^{x}$ Means compared within season at $P \leq 0.05$.

seasons, leaf $\mathrm{N}$ concentration of both cultivars responded quadratically to $\mathrm{N}$ rate, but leaf $\mathrm{N}$ concentration increased minimally with $>168$ $\mathrm{kg} \mathrm{N} /$ ha (Table 1). Leaf P concentration increased linearly with $\mathrm{N}$ rate. The $\mathrm{P}$ concentrations were, however, within the sufficiency range for collards (Jones et al., 1991). Other leaf nutrient concentrations were not affected by $\mathrm{N}$ rate. 'Blue Max' leaf mineral nutrient concentrations, therefore, were not consistently higher than those of 'Vates', despite differences in greens production.

Except for $\mathrm{Ca}$, leaf mineral nutrient concentrations reported in these experiments were within sufficiency ranges for collards (Jones et al., 1991 ). The mean Ca concentrations obtained for 'Blue Max' and 'Vates' were $1.41 \%$ and $1.74 \%$, respectively (Table 1). Higher $\mathrm{Ca}$ concentrations have been reported for 'Vates' confirm the superior yield potential of 'Blue Max', a hybrid, compared to 'Vates', an open-pollinated cultivar. 'Blue Max', but not 'Vates', responded to the addition of $>112 \mathrm{~kg}$ $\mathrm{N} / \mathrm{ha}$ in spring. In fall, yield differences between 'Blue Max' and 'Vates' at the $0 \mathrm{~kg} \mathrm{~N} / \mathrm{ha}$ rate further substantiate the superior yield potential of 'Blue Max'. This impressive response may indicate the capacity of 'Blue Max' to produce high yields when planted as a double crop, without additional fertilizer, as is a common practice among collard growers. Yields were consistently higher for 'Blue Max' than 'Vates' at the other $\mathrm{N}$ rates. We found no evidence that its high yield resulted from improved mineral nutrition. The productivity of 'Blue Max' may be due to its extensive rooting system (Johnson, 1991 b). The reduced yield with increased within-row spacing confirms the results of experiments with other crucifers and suggests that the response to within-row spacing is the same for hybrid and open-pollinated collard cultivars. In conclusion, the results of these studies confirm the high yield potential of 'Blue Max' collards, establish a benchmark for an $\mathrm{N}$ application rate of 112 $\mathrm{kg} \cdot \mathrm{ha}^{-1}$ for collards grown in single rows from transplants, and suggest that high yields of standard and hybrid collard cultivars may be obtained at $15-\mathrm{cm}$ within-row spacings and a $1.2-\mathrm{m}$ row spacing.

\section{Literature Cited}

Beverly, R.B., W.M. Jarrell, and J. Letey, Jr. 1986. A nitrogen and water response surface for sprinkler-irrigated broccoli. Agron. J. 78:9194.

Csizinszky, A.A. and D.J. Schuster. 1985. Response of cabbage to insecticide schedule, plant spacing, and fertilizer rate. J. Amer. Soc. Hort. Sci. 110:888-893.

Cutcliffe, J.A. 1975. Effect of plant spacing on single-harvested yields of several broccoli cultivars. HortScience 10:17-419.

Dufault, R.J. and L. Waters, Jr. 1985. Interaction of nitrogen fertility and plant populations on transplanted broccoli and cauliflower yields. HortScience 20: 127-129.

Hill, T.R. 1990. The effect of nitrogenous fertilizer and plant spacing on the yield of three Chinese vegetables-kai lan, tsoi sum and pak choi. Scientia Hort. 45(1990):11-20.

Hue, N.V. and C.E. Evans. 1986. procedures used for plant and soil analysis by the Auburn University Soil Testing Laboratory. Dept. of Agron. and Soils Dept. series no. 106, Auburn Univ., Ala.

Johnson, J.R. 1991a. Calcium accumulation, calcium distribution, and biomass partitioning in collards. J. Amer. Soc. Hort. Sci. 116:991-994.

Johnson, J. 1991b. Calcium nutrition and cultivar influence incidence of tipburn of collard. HortScience 26:544-546.

Jones, J.B., Jr., B. Wolf, and H.A. Mills. 1991. Plant analysis handbook. Micro-Macro Publishing, Athens, Ga. p. 177-180.

Kahn, B.A. 1990. Reduced plant populations save seed costs without reducing yield or quality of 'Alltop' turnipgreens. HortScience 25:179-180.

Knavel, D.E. and J.W. Heron. 1981. Influence of tillage system, plant spacing, and nitrogen on head weight, yield, and nutrient concentration of spring cabbage. J. Amer. Soc. Hort. Sci. 106:540545 . 
Kowalenko, C.G. and J.W. Hall. 1987. Effects of nitrogen applications on direct-seeded broccoli from a single harvest adjusted for maturity. J. Amer. Soc. Hort. Sci. 112:9-13.

Letey, J., W.M. Jarrell, N. Valoras, and R. Beverly. 1983. Fertilizer application and irrigation management of broccoli production and fertilizer use efficiency. Agron. J. 75:502-507.

Massey, P.H., Jr., J.F. Eheart, T.W. Young, and G.E. Mattus. 1962. The effect of soil moisture, plant spacing, and leaf pruning on the yield and quality of broccoli. Proc. Amer. Soc. Hort. Sci 81:316-323.

Olson, S.M. and P.J. Stoffella. 1989. Yield stability differences among collard cultivars. HortScience 24:495-497.

Palevitch, D. 1970. Effects of plant population and pattern on yield of broccoli (Brassica oleracea var. italica) in single harvest. HortScience 5:230231.
Perkins, H.F. 1987. Characterization data for selected Georgia soils. College of Agr., Univ. of Georgia. p. 343-355, 363-377.

Stofella, P.J. and M.F. Fleming. 1990. Plant population influences yield variability of cabbage. J. Amer. Soc. Hort. Sci. 115:708-711.

White, J.M. and R.B. Forbes. 1976. Effect of spacing and fertilizer rates in cabbage yield and head weight. Proc. Fla. State Hort. Soc. 89:118-120. 